\title{
Policies and Strategies for Reducing Stunting through The Community Empowerment Model
}

\author{
Bambang Budi Raharjo ${ }^{1}$, Sofwan Indarjo ${ }^{2}$, Efa Nugroho ${ }^{3}$ \\ \{bambangbr@mail.unnes.ac.id ${ }^{1}$, sofwan_indarjo@yahoo.co.id ${ }^{2}$, \\ efa.nugroho@mail.unnes.ac.id ${ }^{3}$ \} \\ Universitas Negeri Semarang, Semarang, Indonesia ${ }^{1,2,3}$
}

\begin{abstract}
WHO (World Health Organization) has set a maximum limit of stunting sufferers that is $20 \%$ of the total number of children under five. In Indonesia, the percentage of stunting toddlers in 2018 according to the results of the Basic Health Research (Riset Kesehatan Dasar) was $30.8 \%$ even reaching $37.2 \%$ in 2013 . The number of stunting in Demak in 2013 was $50.28 \%$ (50,780 toddlers). Various efforts and programs have been carried out but have not reached maximum results, in 2019 the incidence of stunting in the Demak Regency is still 50.23\% (48,829 children under five years old) and $4.29 \%$ (6,129 children under five years old) potentially stunting. The purpose of this study was to determine the policies and strategies for stunting prevention through community empowerment models. This research used a systematic review design. Articles were obtained from various sources and then filtered to get the core articles to be analyzed. One of the results of the research is that the BKKBN has developed the Kampung KB program. The spirit of forming and establishing Kampung KB throughout the archipelago has resulted in hundreds of Kampung KB. The presence of Kampung $\mathrm{KB}$ aimed to improve the quality of life of the community at the village level or equivalent through the Bangga Kencana program and the development of other sectors to create quality small families including on the family health side. It is hoped that the influence of the optimization of the Kampung KB as a strategy for the acceleration of stunting countermeasures.
\end{abstract}

Keywords: Stunting, Policy, Community Empowerment.

\section{$1 \quad$ Introduction}

Stunting or dwarf disease is one of the nutritional problems experienced by toddlers, where toddlers experience a condition of failure to grow due to chronic malnutrition so that the toddler is too short for his age [1]. Stunting is a continuation process that does not happen suddenly [2]. Broadly speaking, stunting is caused by a lack of 
nutritional intake in a long time and the occurrence of recurrent infections, and both of these causes are influenced by inadequate parenting from the womb until the first 1,000 days of birth [3].

Chronic malnutrition that occurs in stunting toddlers is caused by poor parenting practices, limited health services, lack of access to nutritious food, and lack of access to clean water [4]. Another opinion according to Khoirun Ni'mah and Siti Rahayu Nadhiroh (2015), in their research shows that low birth length, toddlers who do not get exclusive breastfeeding, low family income, low maternal education, and lack of mother's nutritional knowledge are factors related to the incidence of stunting in infants [5]. Another study according to Farah Okky Aridiyah (2015) also showed that the factors that influence stunting in children under five in rural and urban areas are mother's education, family income, mother's knowledge about nutrition, exclusive breastfeeding, age of MP-ASI, level of Adequacy of zinc and iron, a history of infectious diseases and genetic factors [6]. According to the Ministry of PPN / Bappenas, the causes of stunting are classified into 2 (two) namely direct and indirect causes. The cause is directly related to nutrition and health status, while the cause is not directly related to other factors outside health such as food security, social environment, health environment, and residential environment.

The magnitude of the impact of stunting made the government pay great attention to this problem. To handle this case, cross-sector involvement is needed. Including BKKBN. As a government institution that is concerned with population problems, BKKBN has specific and concrete activities in overcoming stunting, namely through the Population, Family Planning and Family Development (KKBPK) program which has now changed its name to Proud Kencana which is short for "Pembangunan Keluarga, Kependudukan dan Keluarga Berencana". Bangga Kencana Program has many benefits for families. In terms of health, the Proud Kencana program is beneficial for mothers and children. For Mothers, the Bangga Kencana program can: a) Prevent anemia (lack of blood); b) KB can maintain health physical and reproductive health more optimal; c) Prevent excessive bleeding after childbirth and accelerate recovery of uterine conditions; d) Prevent Unwanted Pregnancy; e) Closer to the mother in health services; f) Increase the harmony of the family For children, the program Bangga Kencana can: a) Prevent malnutrition in children; b) Growth and development ak guaranteed; c) 6 months exclusive breastfeeding needs can be fulfilled. The efforts made in order to improve the achievements of the Bangga Kencana program are the establishment of a Kampung KB.

In general, the purpose of the establishment of the Kampung KB is to improve the quality of life of the community at the village level or equivalent through the Bangga Kencana program and the development of other related sectors in order to create quality small families. Whereas specifically, the Kampung KB was formed in addition to increasing the participation of the government, non-governmental and private institutions in facilitating, assisting and fostering the community to carry out the program and related sector development, also to increase public awareness about population-oriented development and community health development.

This is certainly in line with the problems being faced in Demak Regency. The high stunting rate in the Regency is expected to be suppressed by the intervention of the Kampung KB program which is modified according to the needs and characteristics of the people of Demak Regency. 
Related to stunting, WHO (World Health Organization) has set a maximum limit of stunting sufferers, which is $20 \%$ of the total number of children under five. In Indonesia, the percentage of stunting toddlers in 2018 according to the results of the Basic Health Research (Riskesdas) was 30.8\%, even reaching 37.2\% in 2013. In the context of overcoming and accelerating the reduction of stunting in Indonesia, the government then set 1,000 priority villages stunting intervention in 100 districts / cities and 34 provinces [7,8]. The determination of 100 priority districts / cities is determined by looking at indicators of the number of stunting children under five, the prevalence of stunting, and the level of poverty until at least 1 district / city has been selected from all provinces, one of which is Demak Regency. The incidence of stunting in Demak Regency in 2013 was 50.28\% (50,780 toddlers). Various efforts and programs have been carried out but have not yet reached maximum results, in 2019 the incidence of stunting in Demak Regency is still 50.23\% (48,829 children under five years old) and 4.29\% (6,129 children under five years old) potentially stunting [9].

The purpose of this study was to determine the effect of family planning optimization optimization interventions in improving community knowledge, attitudes, and practices as a Strategy for the Acceleration of Stunting Countermeasures in Demak Regency.

\section{Method}

\subsection{Reserch design}

This study uses a Randomize Control Trial (RCT) design designed to find out the effects of family planning optimization optimization interventions on villages with stunting toddlers in Demak Regency.

\subsection{Population and sample}

The population in this study included parents of toddlers who experienced stunting in Demak Regency.

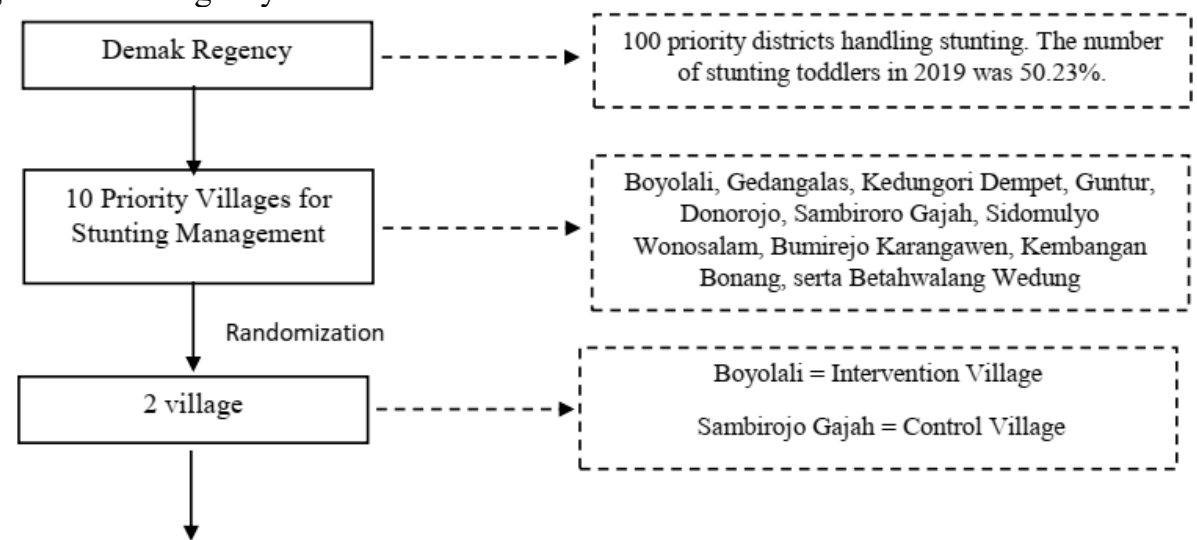

Sample Selection 
Fig. 1. Justification of Locus Selection, Population, and Research Samples

According to the inclusion criteria, 64 parents were selected to participate in the study. They were randomly divided into two groups: control and experimental groups (32 in each group). Inclusion criteria for patients are: parents who have stunting toddlers, are willing to participate, and live in Demak Regency. Exclusion criteria did not participate in one of the training sessions.

\subsection{Data collection}

Data were collected using 2 questionnaires. The first questionnaire was the Indonesian version of The Health Promoting Life Style Profile II (HPLP II) and a questionnaire prepared by researchers based on the PRECEDE-PROCEED model.

The HPLP II questionnaire was first developed by Walker et al in 1978. In the current study a multidimensional assessment was carried out by assessing health promotion behavior in six aspects namely nutrition (7 items), physical activity (7 items), responsibility for health (13 items), stress management (6 items), interpersonal relationships ( 8 items), and self-actualization (11 items). The questionnaire included 52 questions based on a four-item Likert scale with ratings: never $=1$, sometimes $=2$, often $=3$, and always $=4$. Total health promotion behavior scores between 52 and 208 with higher scores indicate a sedentary lifestyle healthier. For each aspect of behavior, scores are calculated separately. Therefore, the score for each subscale is calculated by the answer score given to questions from the same subscale. In each subscale and in the total scale, reaching less than $50 \%$ of the total score indicates bad status, $50 \%$ to $75 \%$ represents average status, and greater than $75 \%$ indicates good status.

The second questionnaire was prepared by the researcher based on the PRECEDE-PROCEED Model based on information found in the literature review. The questionnaire has four parts namely demographic information (including age, sex, subject and parent education, and occupation of the parents), predisposing factors (including 10 questions about knowledge and 15 questions about attitudes towards healthy lifestyle), supporting factors ( including four questions to measure stress management skills, interpersonal relationships, self-actualization, access to and use of training resources), and reinforcement factors (consisting of three questions to measure support and encouragement of peers, family and health service staff). Questions related to knowledge, possible factors, and reinforcement factors are scored in the form of Yes $=1$ and No $=0$, while attitude questions are scored based on a 4-item Likert scale that ranges from strongly disagree $=1$ to strongly agree $=4$. Therefore, the total score ranges from the predisposing factors section to 25-70, the supporting factors section from $0-4$, and the reinforcement factors section from 0-3 (higher scores indicate better health status).

\section{Results and discussions}

\subsection{Stunting}


Stunting is a chronic malnutrition problem that is caused by a lack of nutrition in a long time due to the provision of food that is not appropriate to nutritional needs. Stunting occurs when the fetus is still in the womb and only appears when the child is two years old. Nutritional deficiencies at an early age increase infant and child mortality, cause sufferers to get sick easily and have a posture that is not optimal as an adult [10].

Stunting in infants is a consequence of several factors that are often associated with poverty including nutrition, health, sanitation and the environment. The main factors causing stunting are: Humans need food for their survival [11]. Food is a source of energy to support all activities or human activities. A person cannot produce energy in excess of what is obtained from food unless he borrows or uses energy reserves in the body. But this habit of borrowing can lead to serious conditions, namely malnutrition, especially energy. The condition of poor environmental sanitation allows various types of diseases including diarrhea, helminthiasis, and digestive tract infections. If the child suffers from a digestive tract infection, absorption of nutrients will be disrupted which causes nutrient deficiencies. Someone who is deficient in nutrients will be susceptible to disease and experience growth disorders.

Stunting is a major nutritional problem that will have an impact on social and economic life in society. In addition, stunting can affect children under five in the long term, which is disturbing their health, education and productivity in the future. Stunting children under five tend to have difficulty achieving optimal growth and development potential both physically and psychomotor [12].

Developmental disorder is a condition of the child not being able to achieve the task of development at the estimated time. Disorders can occur in many areas of development, for example in motor, language, social, or thinking. Stunting that occurs during childhood is a risk factor for increased mortality, cognitive abilities, and low motor development and unbalanced bodily functions [13].

\subsection{Kampung KB}

Hearing the term "Kampung", the impression that arises in our minds will definitely be aimed at a place of residence of a group of people or families with all the backwardness, limitations, lagging, old-fashioned, slum, remote, and several other designations associated with the village.

We cannot deny that the village is very identical with such terms, so is the case with the KB Village which has recently become a popular icon not only among the BKKBN, but has also been widely discussed by departmental institutions or nondepartmental level from the regional level to the central level.

Indeed, since the KB Village was announced by the President of Indonesia (Ir. Joko Widodo) in January 2016, that the KB Village has been widely discussed by the public from the lower classes, the middle to the elite, and even writings on the KB village many fill in the news columns in the mass media (newspapers, magazines, tabloids) and even become quite hot and popular news in the electronic media.

So why is this $\mathrm{KB}$ village established, there are a number of things behind it, namely: (1) the KB program no longer resonates and sounds echoed like in the New Order era, (2) to improve the quality of life of people at the village level or equivalent through the Proud program Kencana and related sector development in order to realize quality small families, (3) strengthening the Proud Kencana program which is 
managed and organized from, by and for the community, (4) realizing Indonesia's development ideals as contained in Nawacita especially the 3rd priority agenda, namely "Starting development from the periphery by strengthening regions and villages within the framework of a unitary state "and the 5th Priority Agenda, namely" Improving the quality of life of the Indonesian people", (5) promoting and reviving family planning programs to welcome the achievement of demographic bonuses that are predicted to occur in in $2010-2030$.

\subsection{Kampung KB as a forum for community empowerment}

Although the establishment of the Kampung KB is mandated by the BKKBN, in principle the Kampung KB is a manifestation of the synergy between several relevant ministries from the central government and regional governments, work partners, and stakeholders, and does not miss the direct participation of the local community. Therefore, this Kampung KB is expected to be a miniature or portrait (portrait) of a village in which there is integration of the Population, Family Planning and Family Development programs which are synergized with related sector development programs which are carried out systematically and systematically, including in the health sector development. .

The Kampung KB was actually designed as an effort to ground, reappoint, and revitalize the Proud Kencana program to bring access to services to families and communities in an effort to actualize and apply 8 (eight) whole family functions in the community. Thus the activities carried out in the Kampung KB are not only identical to the use and installation of contraception, but are an integrated development program and integrated with various other development programs. So that we can make this Kampung KB forum a vehicle for community empowerment through various programs that lead to efforts to change people's attitudes, behaviors and ways of thinking towards a better way.

The aim of the intervention is to obtain positive changes from behavior modification in the six aspects of HPLP in the experimental group. Initially, a four-phase PRECEDE assessment is carried out and then appropriate interventions based on the assessment are developed, implemented and evaluated.

Interventions that are developed refer to the theoretical framework of behavior change communication. To accelerate the handling of health problems, strategic interventions need to be developed that include policies, organizations, communities, interpersonal, and individuals. 


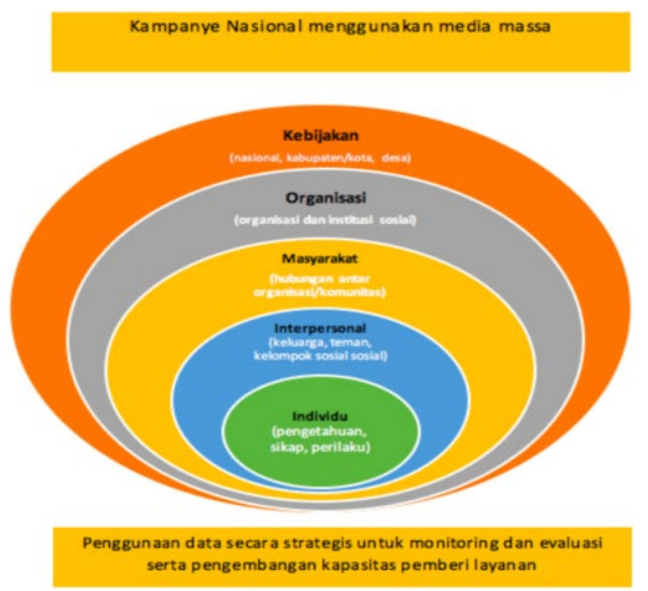

Fig. 2. Intervention Model Framework

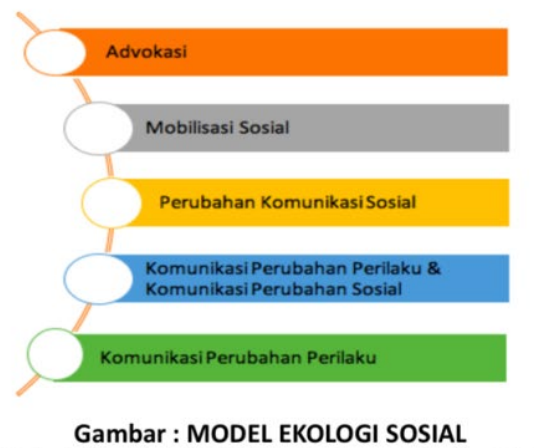

Diadaptasi Dari Unicef/EAPRO Regional Communication Guide 2013

Kampung KB is a village-level regional unit with certain criteria in which there is an integration of the Proud Provisional program and related sector development carried out systematically and systematically. It is hoped that the formation of the Kampung KB program by BKKBN is expected to carry out the Proud of the Kencana program and other development programs in an integrated and concurrent manner. The purpose of the formation of the Kampung KB is to improve the quality of life of families and communities through the Proudly Proposed program integrated with other development sectors. The Kampung KB Program will then be optimized in the form of activity in accordance with the framework of the intervention model, namely advocacy, social mobilization, social communication change, and behavior change communication. In detail are:

\section{a. Advocation}

. Socialization of Demak Regent Regulation Number 29 Year 2019

In an effort to optimize the KB village program to cope with the stunting incident in Demak, the initial step taken is advocacy to policy makers in the Kampung KB area such as the Village Head, RW Chairperson, and RT Chairperson. This advocacy began with the socialization of Demak Regent Regulation No. 29 of 2019 concerning the Stunting Management Regional Action Plan in Demak Regency in 2019-2021. This regulation concerning the Regional Government action plan that contains programs and activities in the field of stunting countermeasures in order to realize quality and competitive human resources, so that with socialization to policy makers it is expected that they will be able to know and understand the contents of these regulations and commit to participate in efforts to prevent stunting by optimizing the Kampung KB program [14].

Proposed Village Regulations Regarding Stunting 
The results of the advocacy activities that have been carried out to policy makers are expected to produce related Village Regulations on optimizing family planning villages in overcoming stunting in the region.

\section{b. Social Mobilitation.}

In the opinion of Soerjono Soekanto, the understanding of social mobility is a movement in social structure, that is, certain patterns that govern the organization of a social group. In this activity required the formation of organizing in the form of cadres with the program: 1) Formation of cadres concerned with stunting. The formation of these cadres is to coordinate if there are stunting to be referred and handled. 2) Data collection and examination of pregnant women. The importance in overcoming stunting starts from pregnant women, in this activity the cadres list all pregnant women to carry out pregnancy-related examinations. 3) Early detection of stunting cases: In this activity the cadres detect all toddlers in prevention efforts and if there is detected stunting, the cadres immediately make a referral.

\section{c. Change in social communication}

. Wilbur Schramm through his study commissioned by UNESCO examines the role of communication in national development. In his report entitled Mass Media and National Development: The Role of Information in Developing Countries, in 1964, Schramm stated the role of mass media in national development as an agent of social change. The location of its role is to help accelerate the process of transition from traditional societies to modern societies. In particular the transition from habits that hinder development to new attitudes that are responsive to reform for development [15]. Development is expected to be carried out voluntarily in which every individual takes part in it and information about development is received equally. With this in mind, family planning changes can be implemented in social communication to provide education in increasing the level of knowledge targeting pregnant and lactating women and mothers with children under five. This activity takes place at the posyandu by providing: 1) Stunting Education. This activity provides knowledge of the causes and effects of stunting. 2) Education of 1000 HPK. This educational activity provides knowledge of how important 1000 HPKs are related to family education, especially mothers during pregnancy, childbirth and breastfeeding, nursing care for infants and toddlers.

\section{d. Communication change behavior}

. In the Kampung KB there is a Toddler Family Development Program (BKB), this activity provides cadres counseling stimulation of child development and counseling for families who have toddlers. This program can also be used to provide education regarding $1000 \mathrm{HPK}$ to fertile age couples.

Behavior change communication can also be provided to adolescents through the Youth Information and Counseling Center (PIK-R) program. PIK-R is a forum for PKBR program activities managed from, by, and for adolescents to provide information and counseling services on Family Life Planning for Adolescents and other supporting activities including education related to stunting [16]. 


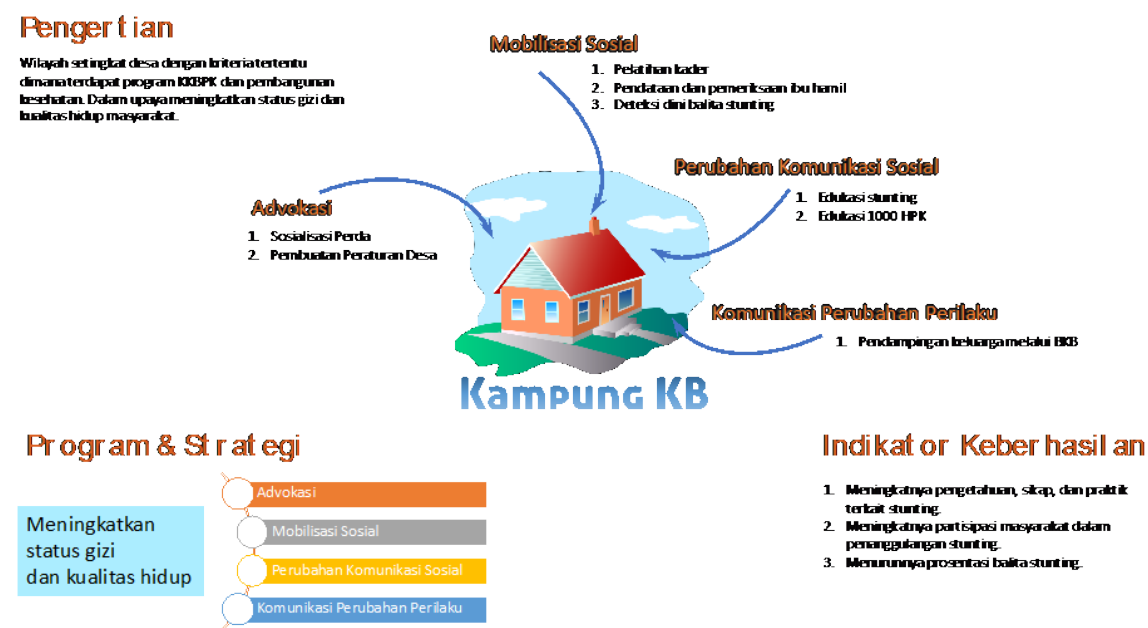

Fig. 3. Optimization of the KB Village as a Strategy for the Acceleration of Stunting in the District of Demak

\section{Process Evaluation}

Process evaluation occurs during program implementation and is used to evaluate the process in which the program is run. In this phase, the achievement of intervention goals is measured. In this study, process evaluation includes evaluating program components such as program staff, methods, materials used, and activities.

Impact Evaluation

This phase determines the direct effect of the program on target behavior, and it occurs after the program ends. In this study, impact evaluation consists of assessing changes in predisposing, reinforcing, and enabling factors that influence behavior immediately after and one month after intervention activities through questionnaire analysis.

\section{Conclusions}

The results of the research is that the BKKBN has developed the Kampung KB program. The spirit of forming and establishing Kampung KB throughout the archipelago has resulted in hundreds of Kampung KB. The presence of Kampung KB aimed to improve the quality of life of the community at the village level or equivalent through the Bangga Kencana program and the development of other sectors to create quality small families including on the family health side. It is hoped that the influence of the optimization of the Kampung KB as a strategy for the acceleration of stunting countermeasures. The intervention is still ongoing, so for the results of the effectiveness of the intervention cannot be reported.

\section{References}


[1] Budhathoki SS, Bhandari A, Gurung R, Gurung A, Kc A. Stunting Among Under 5-YearOlds in Nepal: Trends and Risk Factors. Matern Child Health J. 2019:1-9.

[2] Tanjung C, Prawitasari T, Sjarif DR. Comments on "Stunting is not a synonym of malnutrition." Eur J Clin Nutr. 2020:3-4.

[3] Habimana S, Biracyaza E. Risk Factors Of Stunting Among Children Under 5 Years Of Age In The Eastern And Western Provinces Of Rwanda: Analysis Of Rwanda Demographic And Health Survey 2014/2015. Pediatr Heal Med Ther. 2019; 10:115-130.

[4] Titaley CR, Ariawan I, Hapsari D, Muasyaroh A, Dibley MJ. Determinants of the stunting of children under two years old in Indonesia: A multilevel analysis of the 2013 Indonesia basic health survey. Nutrients. 2019;11(5).

[5] Nadhiroh, Siti Rahayu; Ni'mah K. Faktor yang berhubungan dengan kejadian. Media Gizi Indones. 2010;1:13-19.

[6] Aridiyah FO, Rohmawati N, Ririanty M. Faktor-faktor yang Mempengaruhi Kejadian Stunting pada Anak Balita di Wilayah Pedesaan dan Perkotaan. J Pustaka Kesehat. 2015;3(1):163-170.

[7] Dinas Kesehatan Propinsi Jawa Tengah. Profil Kesehatan Jawa Tengah.

[8] Kementerian PPN. Rencana Aksi Nasional dalam Rangka Penurunan Stunting: Rembuk Stunting. Jakarta: Kementerian Kesehatan Republik Indonesia; 2018.

[9] Profil Kesehatan Kab. Demak, https://rive.google.com/file/d/14gzaQGrHHypirkUCIhWDb5A7V03yOuX/view, last accessed: 17 June 2020.

[10] Aguayo VM, Nair R, Badgaiyan N, Krishna V. Determinants of stunting and poor linear growth in children under 2 years of age in India: An in-depth analysis of Maharashtra's comprehensive nutrition survey. Matern Child Nutr. 2016;12:121-140.

[11] Woldeamanuel BT, Tesfaye TT. Risk Factors Associated with Under-Five Stunting, Wasting, and Underweight Based on Ethiopian Demographic Health Survey Datasets in Tigray Region, Ethiopia. J Nutr Metab. 2019;2019.

[12] Alderman H, Nguyen PH, Menon P. Progress in reducing child mortality and stunting in India: An application of the Lives Saved Tool. Health Policy Plan. 2019;34(9):667-675.

[13] Rezapour B, Mostafavi F, Khalkhali HR. School-Based and PRECEDE-PROCEEDModel Intervention to Promote Physical Activity in the High School Students: Case Study of Iran. Glob J Health Sci. 2016;8(9):271.

[14] Astuti S, Megawati G, Samson C. Gerakan Pencegahan Stunting Melalui Pemberdayaan Masyarakat Di Kecamatan Jatinangor Kabupaten Sumedang. Dharmakarya. 2018;7(3):185-188.

[15] Calano BJD, Cacal MJB, Cal CB, et al. Effectiveness of a community-based health programme on the blood pressure control, adherence and knowledge of adults with hypertension: A PRECEDE-PROCEED model approach. J Clin Nurs. 2019;28(9-10):1879-1888.

[16] Bazpour M, Gheibizadeh M, Malehi AS, Keikhaei B. The effect of a training program based on the PRECEDE-PROCEED model on lifestyle of adolescents with BetaThalassemia: A randomized controlled clinical trial. Int J Hematol Stem Cell Res. 2019;13(1):12-19. 